discourse, however, did not give British administrators a stable hegemony and was used by both Waluguru and administrators in flexible ways. I shall argue that the construction and use of a reified concept of Luguru custom can be better understood as a process of "pidginization" in circumstances of large power differences between substrate and superstrate political languages.

representation and pidginization

In Africanist historiography, "invented traditions" were first identified in order to distinguish "authentic" ones: "invented traditions" were things against which students of African history had to "defend" themselves in order to reach the "really pivotal" traditions of, in this case, Lozi history (Prins 1980:8, 12). This led Prins to support Horton and Soyinka by saying that the colonial factor was a mere "catalytic incident" in African history (1980:15), a denial of historical change and a further reification of culture that few students of colonial history will accept. Terence Ranger also sees invented traditions as "false models of colonial codified African 'tradition,' " but-adding that they became colonial realities (1983:212)-clearly thinks they were more than incidental. He also interprets them, however, as an inauthentic "ideology" imposed by colonizers and shared, against their interests, by the colonized $(1983: 229,236)$.

The issue of the (in)authenticity of "traditions" may be more important than the emphasis on their reification. The latter often fails to integrate analytically the interactions between colonizers and colonized (Thomas 1992:213). It also fails to address the historical impact of a (Western) discourse on the truth or falsity-the "authenticity" —of knowledge of other cultures within these interactions. Contemporary apologists of indirect rule generally emphasized the necessity of "true" representations of indigenous institutions to create legitimate rule (Cameron 19.37; Fortes and Evans-Pritchard 1940:1, 15; Malinowski 1929; Perham 1934). Critics of indirect rule stressed the way in which European government on African lines created "false" representations of indigenous tradition (Graham 1976; Ranger 1983). These opposed interpretations of colonial history both rely on a discourse of representation-that is, a discourse on the truth, or falsity, of ethnographic statements about "others."2

I submit that to understand the involvement of Waluguru and British in the implementation of indirect rule, one should not focus on the authenticity of the content of colonial representations but on the institution of representation (both political and textual) as such. In an important contribution to the debate, Timothy Mitchell has argued that a Western discourse of representation transformed Egyptian political discourse from a shifting play of difference into an attribution of certain, unambiguous, and stable meanings to political concepts (1991:138): a step toward the reification of custom and culture mentioned above. This effect is achieved through an ordering discipline of "enframing," a method of dividing up and containing social practices in a "neutral" space that creates the illusion of an independent, objective, or natural system of magnitudes (1991:44-45). Enlisting Foucault in the service of Derrida, Mitchell writes that in its way, "political power, however microphysical in its methods, operates always so as to appear as something set apart from the real world" (1991:160; emphasis added). It does this by creating the "theological effect" of an absent, objective referent that conceals its author and its political authority at the same time $(1991: 146,154)$.

Mitchell's account contains much of value, particularly when he points out the redundancy of widely dispersed ordering and classifying activities that under colonial rule were condensed in statistical surveys and the census (Anderson 1991; Cohn 1987; Rafael 1994). But his theory presupposes a kind of hegemony that contains all modes of resistance " within the organizational terrain of the colonial state" (Mitchell 1991:xi). Mitchell cannot conceive theoretically of the interaction between a Western discourse on representation and the forms of production of meaning that it transforms: the latter are only addressed as fundamentally "other" to the former, which reproduces an essentialization of otherness upon which the colonial discourse that he 


\title{
the pidginization of Luguru politics: administrative ethnography and the paradoxes of indirect rule
}

\author{
PETER PELS-University of Amsterdam
}

The study of "colonialism" faces a paradox: while its object is increasingly recognized as crucial to any understanding of the practice of anthropology, it has at the same time lost the meaningful unity of a systematic and intentional project of rule (Dirks 1992:7; Thomas 1994:ix).' While the term colonialism suggests that one can outline a certain order imposed by colonizers on colonized societies, the study of this order unveils "tensions of empire" among colonizers (Cooper and Stoler 1989). When the balance between strategies of coercion, persuasion, collaboration, and resistance employed by both colonizers and colonized is drawn up, "colonialism" fragments into contingencies (Guha 1989:230). It turns out that the concept of "hegemony" has too often lent a spurious unity to the power relationships between colonizer and colonized, perpetuating the failure of both colonialist and anticolonialist historiography "to discern the anomalies that made colonialism into a figure of paradox" (Guha 1989:213).

The contradiction in terms of "indirect rule" exemplifies the tensions of empire (Cooper and Stoler 1989:616), and an echo of its paradoxicality can be heard in its description as an "invention of tradition" (Ranger 1983). But if an "invented tradition" is taken to be a successful transformation of a politics of "competition, movement and fluidity" into a rigid code of unchanging custom (1983:248-251), one may doubt whether the terms cover the full range of imperial tensions, negotiations, manipulations, and paradoxes that characterized indirect rule. In the following study of the implementation of indirect rule in the Uluguru Mountains of Eastern Tanganyika in the 1920s and 1930s, I hope to show that it did not completely "invent" Luguru standards of legitimate leadership and that its reified concept of Luguru "tradition" masked a number of shifts and renegotiations, sometimes directly occasioned by the flexible use Luguru authorities made of these "traditions." The fact that Waluguru, to this day, distinguish between "traditional" headmen (wakubwa wa jadi) and the headmen appointed by British administrators (wandewa) makes one doubt whether the legitimacy of the invented tradition was ever accepted and should lead us to reconsider the premises of both "invention" and "tradition" and the hegemony that is often ascribed to them. I hope to show that, as elsewhere in Africa (cf. Fields 1985), and perhaps in all administrative ethnography (Pels and Salemink 1994:18), indirect rule did, indeed, add a more rigid dimension to local politics. This reification of Luguru political

The analysis of the tensions of empire that characterize indirect rule is usually hampered by the failure to study critically its discourse of representation and the indigenous resistance and accommodation to it. In this article I make that attempt by describing the administrative ethnography of the Uluguru Mountains in Eastern Tanganyika as a pidgin constructed in a specific contact situation (the baraza, or council meeting) by speakers from both the Luguru substrate or subaltern political discourse and the British superstrate language of political and ethnographic representation. Icolonial discourse, political anthropology, indirect rule, invention of tradition, African historyl

American Ethnologist 23(4):738-761. Copyright O 1996, American Anthropological Association. 
discourse, however, did not give British administrators a stable hegemony and was used by both Waluguru and administrators in flexible ways. I shall argue that the construction and use of a reified concept of Luguru custom can be better understood as a process of "pidginization" in circumstances of large power differences between substrate and superstrate political languages.

representation and pidginization

In Africanist historiography, "invented traditions" were first identified in order to distinguish "authentic" ones: "invented traditions" were things against which students of African history had to "defend" themselves in order to reach the "really pivotal" traditions of, in this case, Lozi history (Prins 1980:8, 12). This led Prins to support Honton and Soyinka by saying that the colonial factor was a mere "catalytic incident" in African history (1980:15), a denial of historical change and a further reification of culture that few students of colonial history will accept. Terence Ranger also sees invented traditions as "false models of colonial codified African 'tradition,' " but-adding that they became colonial realities (1983:212)-_clearly thinks they were more than incidental. He also interprets them, however, as an inauthentic "ideology" imposed by colonizers and shared, against their interests, by the colonized (1983:229, 236).

The issue of the (in)authenticity of "traditions" may be more important than the emphasis on their reification. The latter often fails to integrate analytically the interactions between colonizers and colonized (Thomas 1992:213). It also fails to address the historical impact of a (Western) discourse on the truth or falsity - the "authenticity" - of knowledge of other cultures within these interactions. Contemporary apologists of indirect rule generally emphasized the necessity of "true" representations of indigenous institutions to create legitimate rule (Cameron 1937; Fortes and Evans-Pritchard 1940:1, 15; Malinowski 1929; Perham 1934). Critics of indirect rule stressed the way in which European government on African lines created "false" representations of indigenous tradition (Graham 1976; Ranger 1983). These opposed interpretations of colonial history both rely on a discourse of representation-that is, a discourse on the truth, or falsity, of ethnographic statements about "others." 2

I submit that to understand the involvement of Waluguru and British in the implementation of indirect rule, one should not focus on the authenticity of the content of colonial representations but on the institution of representation (both political and textual) as such. In an important contribution to the debate, Timothy Mitchell has argued that a Western discourse of representation transformed Egyptian political discourse from a shifting play of difference into an attribution of centain, unambiguous, and stable meanings to political concepts (1991:138): a step toward the reification of custom and culture mentioned above. This effect is achieved through an ordering discipline of "enframing," a method of dividing up and containing social practices in a "neutral" space that creates the illusion of an independent, objective, or natural system of magnitudes (1991:44-45). Enlisting Foucault in the service of Derrida, Mitchell writes that in its way, "political power, however microphysical in its methods, operates always so as to appear as something set apart from the real world" (1991:160; emphasis added). It does this by creating the "theological effect" of an absent, objective referent that conceals its author and its political authority at the same time (1991:146, 154).

Mitchell's account contains much of value, particularly when he points out the redundancy of widely dispersed ordering and classifying activities that under colonial rule were condensed in statistical surveys and the census (Anderson 1991; Cohn 1987; Rafael 1994). But his theory presupposes a kind of hegemony that contains all modes of resistance "within the organizational terrain of the colonial state" (Mitchell 1991:xi). Mitchell cannot conceive theoretically of the interaction between a Western discourse on representation and the forms of production of meaning that it transforms: the latter are only addressed as fundamentally "other" to the former, which reproduces an essentialization of otherness upon which the colonial discourse that he 


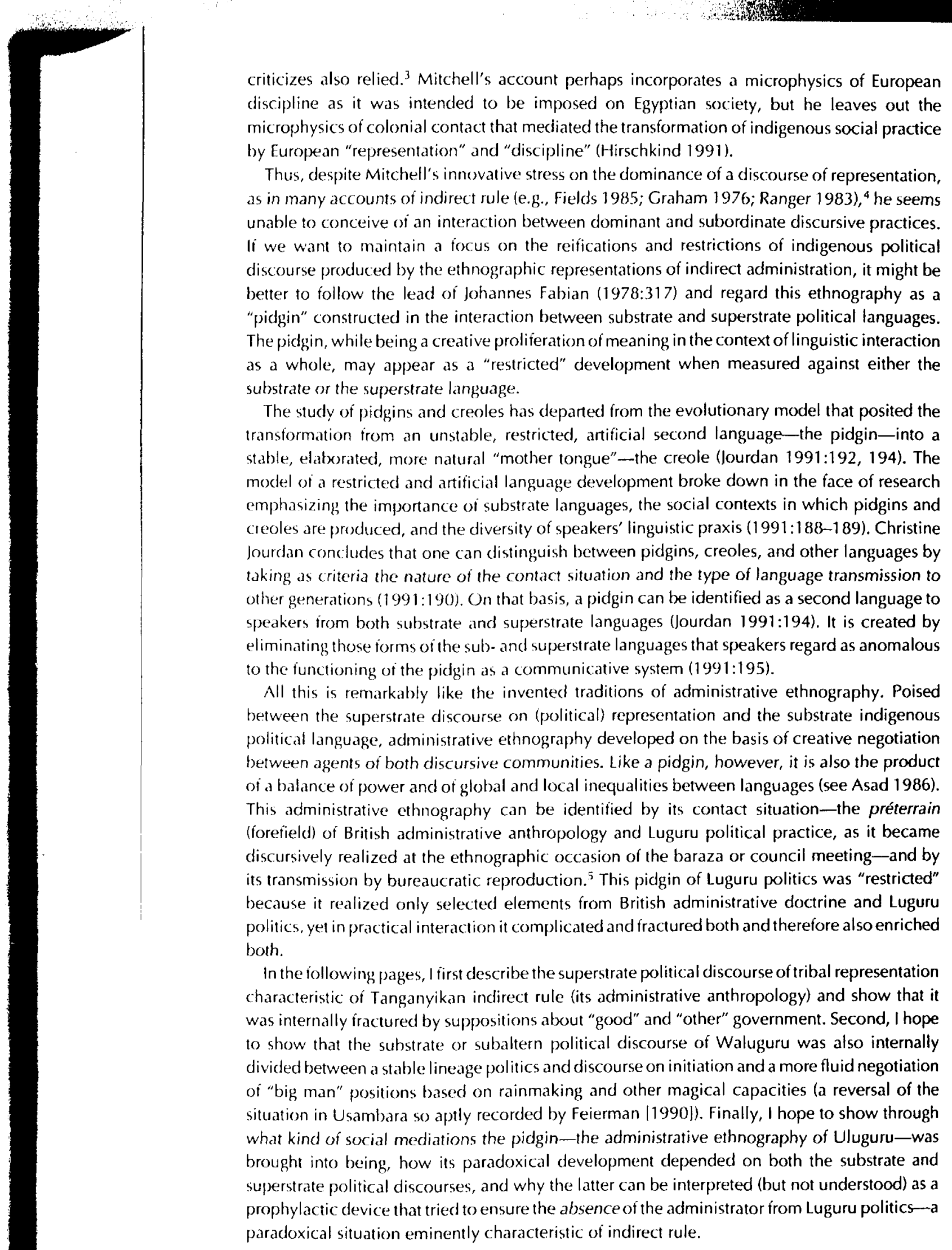


indirect rule as administrative anthropology

It has been argued that the decision to rule through indigenous authorities in Africa was an economical one based on the scarcity of personnel and that, in consequence, the doctrine of indirect rule had little impact when adopted (Fields 1985:32, 41). But in Tanganyika, if not elsewhere, the introduction of indirect rule enabled the state to penetrate society iar deeper than before (Iliffe 1979:325). This was the result of a language of "tribal" representation that, although it had roots in British Indian colonial society, had developed into a distinct, BritishAfrican, political anthropology by the time Donald Cameron implemented it as governor of Tanganyika in 1925.

Although Cameron partly learned his trade when acting as chief secretary to Frederick Lugard in Nigeria, he departed from the latter's policy of calculated noninterierence. Lugard's first interest was to extend military rule-rule by conquest -in a downward direction, that is, to delegate his own authority to native chiefs rather than incorporating theirs (Lugard as quoted in Kirk-Greene 1965:45). In Nigeria, Lugard did not advocate "ruling on African principles," the benevolent protection of native life and the institution of Native Treasuries characteristic of later forms of indirect rule; these were added by subordinate officers inspired by British Indian examples and were vehemently opposed by Lugard (Flint 1978:302-304; Gailey 1974:11; Kirk-Greene 1965:9-11). Instead, Cameron's propensity for anthropological research stems from Lugard's successor as governor of Nigeria, Hugh Clifford, who inherited it from Malayan exemplars, the indirect rule of Rajah Brooke, and Hugh Low in particular. ${ }^{\top}$ When Cameron was appointed governor of Tanganyika in 1925, he insisted, like Clifford, on the necessity of guiding African political evolution, a task that rarely occupied Lugard during his Nigerian years (Gailey 1974:115).

Thus Cameron arrived in Tanganyika in April 1925 with an administrative anthropology largely derived from South (East) Asian colonial rule, a tradition that was both at the roots of and in tension with the budding anthropological profession in Britain. ${ }^{8}$. lis predecessor, Horace Byatt, left Cameron with sufficient staff and revenue for the large-scale administrative reiorm (Gailey 1974:36), which was thought necessary for the purpose of undoing Byatt's ambiguous policy of nominally instituting indirect rule through "tribal" chiefs while at the same time retaining the "nontribal" akida appointed by the Germans. This gave Cameron the additional opportunity to centralize the administration (Ingham 1965:547-552) and wrest the initiative from a group of senior officers, accustomed to the velvet glove of Byatt, who had already started to implement indirect rule after Byatt's departure. ${ }^{9}$ The most forceful personality among them was Charles Dundas, who was as dedicated as Cameron to the promotion of African interests. ${ }^{10}$ Dundas was appointed the first secretary of native affairs of Tanganyika, but he did not get along very well with Cameron. Both agreed on the necessity of ethnography for native administration, but Cameron was dogmatic in his insistence on a theory of "tribes" held together by chieftainships, while Dundas argued that "chiefs" were hard to find in many Tanganyikan societies.

To appreciate this conflict in the administrative hierarchy, and its influence on indirect rule in Uluguru, it is necessary to emphasize again that Cameron substituted the Lugardian delegation of authority to chiefs by the incorporation of mechanisms of tribal colresion. The political evolution that this implied was to be achieved by a process of development from the tribal constitution of the past to local government on British lines in the future, under the advice and control of British officers. In this process the recognition of the present ruler was less important than research into the past tribal constitution, and interference by the political officer was necessary. "The latter emphasis was a result of his commitment to two specific ideas: the akida myth and his theory of tribal cohesion. Cameron thought the Ciermans had intentionally destroyed indigenous institutıons by imposing rule through an akida, who was an alien to the tribe concerned and therefore lacked a traditional position of authority. Lugard preserved 
chiefship by deposing the rulers of Northern Nigeria only to reinstate their relatives later on, but Cameron did not expect to find institutions worth preserving in existence. While his dogmatic view of Tanganyikan history made it imperative to do research, not all of Cameron's officers agreed with it (Gailey 1974:79). ${ }^{12}$ The akida myth provided a scapegoat to which the "defects or weaknesses" of indirect rule could be attributed. ${ }^{13}$ It also emphasized the urgency with which it had to be instituted: to counter the threat of leaderless and uncontrolled, detribalized natives, Cameron's subordinates had to work, to work fast, and on the lines set out by him. This sense of urgency was created by the theory of tribal rule in which Cameron believed and that forms the core of his anthropology.

Unlike the early Lugard, Cameron did not legitimate rule by conquest. ${ }^{14}$ Conquest, including the imposition of purely British standards of government, would create the desire among Africans to take over government. This would turn them into "bad imitations" of Europeans, a phenomenon that Cameron thought was the cause of nationalist troubles in Egypt and india. To Cameron, the "Good African" was an African "from the bottom," still in touch with traditional ways of life and giving his allegiance to his "natural leaders," the chiefs. If the chiefs were incorporated into the system of administration and Africans given an immediate share in their own government, they would perhaps seek more independence-but not on the side of the modern political agitator. ${ }^{15}$

Although Cameron would later acknowledge that chieftaincy was not the only principle of Tanganyikan politics, in 1926, when he published his Native Authority Ordinance, he was convinced that the office of a Native Authority "normally consists of a hereditary tribal chief, almost invariably in association with certain elders and other persons who occupy positions of dignity and responsibility." Despite Dundas's conviction (in 1925) that there were societies in Tanganyika that had never developed institutions of chiefship and were only "democratic and patriarchal," Cameron was at that time far from acknowledging the "essential democracy" of Bantu society that the Tanganyika government claimed before the Permanent Mandates Commission in 1929 (Ingham 1965:567). Tribal consent was, in the words of the East Africa Commission, to be based on the acknowledgment that "hereditary right to authority is an idea still generally recognized in the African mind." Thus Cameron and his officers could switch at will from "tribal institutions" to "tribal constitutions," because institutions were conceived in a legalist sense, as ideas or laws shared by all members of the tribe. ${ }^{16}$ The customs of the tribe were the laws of succession and the laws of succession were hereditary. If Africans did not have their legitimate, hereditary chiefs, tribal organization would be destroyed. Therefore every improvement the administration wanted to make in native society depended on the quality of the chiefs. That meant that the sons of chiefs had to be educated in order to modernize native society; moreover, "extra-tribal" forms of organization such as those created by missionaries had to be guarded so as not to develop into something "political." 17

It is crucial to realize the paradoxical aspects of this attempt to find a baseline for political evolution (compare to Flint 1978:301). By formulating a conception of an "other" politics, Cameron implicated himself in a hierarchy of standards different from that of British politics (Fields 1985). "Representation" of the majority, for instance, could not be the result of elections on European lines-this would merely give room to the agitator. Instead, the chief was supposed to represent his people by their recognition of his hereditary authority. ${ }^{18}$ But that implied that Cameron had to caution his officers not to insist on "the highest standards of English public life," because, were they to do so, they could urge measures that threatened tribal organization. For the appointment of chiefs three principles applied: personal ability, hereditary or traditional right and custom, and the will of the people. The first had to be ignored most often, for "nothing shont of republican government will ensure that a ruler is always a capable man." ${ }^{19}$ Deposition of a chief on the grounds of incompetence meant nothing less than that hereditary or lawful succession was disallowed. "Therewith the foundation of the tribal organization is undermined 
and Chiefs become purely government servants. Therefore rejection on this score must be based on stronger grounds than mere inferiority of intellect and character not amounting to absolute incapacity." Because "hereditary and traditional right substantiates personal claim and warranis the assumption that the people approve," it was clear that of the three principles "hereditary or traditional right" had to be the major one. ${ }^{20}$

Hereditary succession was, of course, not foreign to British politics: it was part and parcel of the aristocratic discourse surrounding the cult of the gentleman. A second aspect of the accommodation to the "African" atmosphere was derived from British public school practice: the emphasis on the "responsibility" of and the "delegation of authority" by the chiefs resembled the ideology of the prefect system. As teachers supervised the prefects, so chiefs had to supervise their subchiefs and administrators their chiefs (Heussler 1963:96-98; Ranger 1983:216). A third aspect of accommodation-and a most successful one-was the fusion of legislative, executive, and judicial functions of government in the office of the chief, another aspect of colonial rule that had been previously tested in India and that was perceived as a pre-Montesquieuian phase of political evolution. Cameron dismissed Chief Justice Russell's protests against severing the connection between native courts and the High Court. Chiefs became the judges of the native courts, in which no barristers (even Africans) could appear in a professional capacity (Moffett 1952:19). ${ }^{21}$

The urgency Cameron felt on account of this theory of tribal representation is made clear by the institution of indirect rule in Uluguru: Chief Muhina Goso Kingo of Northern Uluguru and Chief Kingalu Mwanamfuko of Southern Uluguru were both installed (replacing the akida of their territory) in June 1925, before Cameron asked his District officers to compile notes on the "original constitution" of the tribes in their districts (in September 1925). Although Dundas, supported by the Morogoro District Officer, E. E. Hutchins, proposed a different arrangement after some research had been done, Cameron ignored the anomalies posed for his theory by the fact that Kingo was a conqueror of Northern Uluguru, while Kingalu was in no sense a hereditary chief of South Uluguru. Kingalu was to continue as chief until his deposition in 1936. ${ }^{22}$ Eventually, Dundas had to pay for his opposition to Cameron's theory: his career suffered considerably and lagged behind that of his former assistant, Philip Mitchell.23

Administrative communication was not only hampered by dogmatism at the top but also by (mis)interpretation further down the administrative hierarchy. Many of the subtleties introduced by Cameron in indirect rule doctrine did not reach the lower levels of the administration. F. J. E. Bagshawe, as Provincial Commissioner of the Southern Highlands, issued the following instructions to his subordinates:

Each tribe must be considered a distinct unit. . . Tribal boundaries must be settled. Each tribe must be under a chief. ... The wishes of the whole people must be taken under consideration. . . . Remember always that a chief is a native, with a native's partially developed sense of right and wrong, passions and temptations. Remember that he is your principal weapon in your work and that if he breaks you will have to make another. ... Chiefs must be made to understand that we are increasing their power and paying them salaries and in return we expect a great deal more from them. [Graham 1976:4]

The martial analogies, the sense of European superiority, and the clear emphasis on chiefs as collaborators with the administration, instead of hereditary representatives of their people, show that sometimes there was not much difference between the chief and the akida (Graham 1976:4) and that Lugard's conceptions of authority might still recur among Cameron's subordinates. This was partly the result of the exigencies of administration, which asked for hurried "either-or" decisions instead of painstaking ethnography. As we will see, however, it was less a lack of knowledge as such than the absence of reflection on the way in which ethnographic representations were constructed that made a crucial difference for the construction of indirect rule in Uluguru. 
To understand how indirect rule transformed Luguru political discourse, it is necessary to construct an image of the substrate or subaltern political language that can be contrasted with the "traditional" politics invented by the British. This contrast is more complex than Ranger's juxtaposition of "competition, movement and fluidity" with a rigid administrative code (1983:248). Administrators usually talked or the Luguru "clan system," while later ethnographers used Evans-Pritchard's "segmentary lineage system" (Young and Fosbrooke 1960:39) or one of its modifications (such as the "sub-clan" system [Brain 1973:114]) to conceive of the unity of Luguru socicty. These conceptions were legalistic and reified descent categories predicated, for instance, on the argument that lineage discourse leads to ever-increasing segmentation (Young and Fosbrooke 1960:70-71) or to straightforward progression, without choice or political struggle, to a lineage headmanship (Brain 1973:114). These administrators ignored EvansPritchard's idea that talk of lineages was also a way to discuss other principles of organization (1940:143)-that, in other words, descent categories were a discourse through which political and economic relations werc organized and discussed.

Luguru lineages are traced back 15 generations at most, and these genealogies legitimize the position of the present lineage head, who embodies the power of these ancestors. Descent categories also help to organize relations of production and the exchange of labor. ${ }^{24}$ This does not exclude that some lines of descent are fictitious, and Waluguru clearly distinguish between tracing descent through the female line and tracing it through classificatory kinship (in particular through adopted sister's sons, the wapwa wa kukaribisha). There is therefore room for political maneuvering within lineage relationships-for struggles between parallel lines of descent, between generations, and between men and women-but relationships are never only decided by the skills of the Machiavellian political entrepreneur central to transactionalist analyses (see Thoden van Velzen 1973). Beyond the realm of lineage discourse, however, a political entrepreneur's economic, military, and magical sources of power could well stake out a temporary "big man" position.

This small-scale form of political organization evidently fit a society that, in very recent history, had been composed of small groups of travelers. Threatened by drought, famine, or war, the people who during colonial times were to be named "Waluguru" fled into the mouitains in the beginning of the 19 th century. ${ }^{25}$ Even there they were harassed by Wambunga warriors, Arab slavers, or internecine warfare often caused by the intervention of one or both of these groups. Waluguru commonly refer to the period before the Germans both as wakati wa Wambunga and as wakati wa Waarabu, as Wambunga raids and alliances between Luguru headmen and slave-raiding Arabs took place at the same time. Waluguru seem to have come irom all points of the compass (Mzuanda 1958:7 et passim), but their linguistic similarity to coastal peoples suggests that a majority came from the Eastern plains of Uzaramo and Ukwere. ${ }^{26}$ In the process those Waluguru who possessed cattle lost them through east coast fever, and they seltled down to a purely agricultural economy.

District Commissioner Hutchins's encounter with the Waluguru in 1925-26 took the following ethnographic form:

The tribal system is a clan system (UKOO), which is the strongest I have met with. The people have always paid more attention os their clan-heads than to the German-imposed Jumbes. Marriage within a clan is absolutely forbidden. . . Feeling between the various clans is still very strong and is mainly caused by jealousy, It is this interclan antagonism that has been so difficult to contend with in our efforts to re-establish the old system of tribal administration. It seems as if the family unit were the basis of organization, the elder of the family being appealed to in any matter requiring arbitration. This would also seem to be the foundation unit of the village and the latter to have grown round it. As descent in the tribe is matrilineal the growth or the family into the villages has been a natural outcome of the spread of iamily trees. Thus the family-head also grew into the village head, and, from arbitrating in purely family airairs he came to be the judge upon all village matlers. 
This practice still continues and would appear to suit the immediate needs of the people. It would be a grave mistake to deprive these elders of their powers within the villages, nor would the people wish them to be so deprived. Over each group of villages is an hereditary Ndewa [sic] who rules a small district and is the head of the people living within its boundaries, but iurther than this tribal organization did not originally go. There seem to have been no cohesion amongst the various Wandewa, nor any oi a higher standing than the others. Later on, as the successtul rainmaker became more poweriul, he gradually took over the control of the Wandewa in his particular sphere of work and this appears to have been the way that the families of Kingalo [sic], Hega and Mwanambago gradually became chiets in their respective areas. ${ }^{27}$

Hutchins was correct in stating that the largest formal unit of organization was the area under the nominal authority of an original landholder (mwenye saku or mndewa, plural: wenye saku), and that none of them was capable of exercising substantial authority over the others. His description, however, strongly oversimplified the situation. Moreover, his statement is framed by Cameron's theory of political evolution, according to which the family unit evolved gradually, by the logical extension of family trees and the growth of numbers, into a village, while a group of villages would eventually submit (by consent or by force) 10 a chief, whose prominence was based on mantial and rainmaking powers. ${ }^{28}$ The theory suggested that an emerging rainmaker would eventually occupy a position as politically stable and secure as that of the existing, less-powerful headmen.

When asked, "Who is your chief?" a Mluguru would name a lesser headman, the landholder (mwenye issi [Kiluguru]; mwenye nchi [Swahili]) of the area around one or several hamlets, an area often inhabited by people belonging to one lineage (tombo [Kilugurul, "breast"; ziwa [Swahili]) and some of their affines. The mwenye issi was a first among equals, and his position was legitimated by the genealogy of his ancestors, counted from the first to settle in that specific area. The recitation of the genealogy of landholders (all of whom took the name of the first upon accession to office) was first of all a claim to land; second, it was a claim to prominence in that area of a specific lineage or clan; and only in the last resort was it a claim to authority over all people occupying that land. In a larger unit of territory, usually a mountain valley, several wenye issi would be the nominal inferiors of the original landholder (mwenye saku or mndewa), ${ }^{29}$ the one whose ancestor cleared the first patch of land and thereby established the claim of his clan (Jukolo [Kiluguru]; ukoo [Swahili\}) to that valley; but in practice, they were both advisors and competitors. The people settling on that land, however, were never merely (bio)logical extensions of the family that had settled there first. The concept of lukolo allowed the landholder to accept nominal sister's sons and their families and give them room to settle in the valley. ${ }^{30}$ Thus, contrary to Hutchins's view, the authority of an original landholder was never merely authority over his direct descendants, and lineage discourse could be used both to subdivide territorial groups (in lineages) and to enlarge them (by adoption into the clan).

The order of succession to a landholder's name was never a fixed and logical matrilineal form of descent. Figure 1 displays the possibilities for negotiation. Supposing (1) is the ruling mwenye issi, (2) would be the ideal heir after his death or deposition, or (3) when there are no brothers. Generally, however, a group of women of the lineage-(a) or her mother the most prominent among them-decided whether a candidate was really suitable for the post. They could bypass (2) and (3) and give the name to (4) if he was old enough. An important consideration in this decision was whether the wife of the candidate was also suitable for high office, as she received the same rank as her husband. If (5) inherited the name, however, the chance for fission would increase because of the possibility that the eldest lineage (tombo dikulu [Kiluguru], or "big breast") would at some point in time claim back the right to the name from a middle lineage (tombo magati, or "breast in between") or the youngest (tombo dudogo, or "little breast"). This essential negotiability of descent categories is also apparent from the fact that, at some points in Luguru history, one finds the sons of important headmen laking up a temporary post of prominence and even attempting to change matrilineal into patrilineal descent (and thus to objectify their right to rule). ${ }^{31}$ 


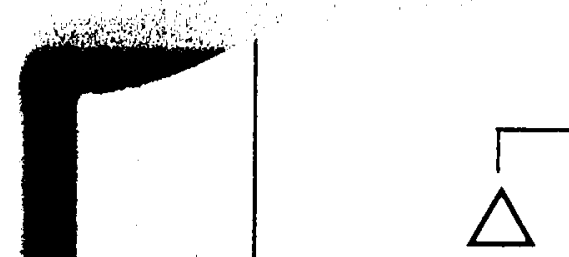

mwenye issi (1)

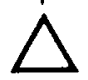

mwenye

issi (2)

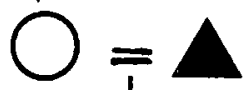

(a)

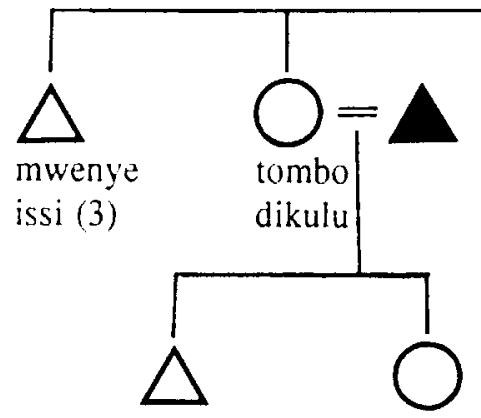

mwenye issi (4)

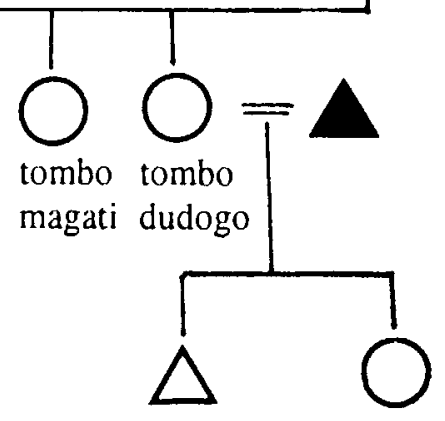

mwenye issi (5)

Figure 1. Luguru kinship discourse. The diagram represents an ideal sequence of succession to male lineage and/or clan headmanship and some alternatives in the selection of suitable candidates. The black symbols indicate a member of a different clan. The order of birth is from left to right.

The integration of these political bodies was further enhanced by the practice of initiation. For Luguru boys, the entrance into the adult world was organized by the inhabitants of the valley or a smaller unit, depending on the power of the landholding clan. Girls were initiated individually or in twos and threes, emphasizing the prominence of the lineage (Pels, in press: chs. 3 and 4). Access to valley politics was also determined by initiation into the local society of wenye mlunga ("those who possess ancestral emblems"), a group of elders (male and female) that included members of other clans, a practice that acknowledged the local influence of the other clans while at the same time tying them to the landholding clan by the magical secrets shared among these initiates. ${ }^{32}$ In this way, the tenants on another clan's land (wapangaji) could enter the political arena.

Landholders were the judges in matters of land and other disputes. They guarded relationships with the ancestors and, through them, regulated agricultural affairs in order to ensure a good harvest (always, however, in consultation with other elders). While a mwenye issi of a specific hamlet would guard the land of his own lineage, the mwenye saku would allocate land to newcomers in the valley as a whole, serve as a court of appeal, and be called upon to act in cases of lack of rain, locust plagues, epidemic illnesses, and other disasters due to the wrath of ancestors. (Before Europeans intervened he also made war medicine.) The secrets of his magical capabilities would be passed on to him when he took the name of his ancestor and received his regalia on accession to office. Since the settlement of the Uluguru mountains, several of the wenye saku had built up reputations bigger than others: the most important of these were Bambarawe in Matombo, Kingalu in Kinole, Hega in Kolero, and Mbago in Mgeta area (see Figure 2). This was partly due to their claim of possessing a place of reconciliation with ancestral or nature-spirits (tambiko) that had far more power for making war-or rain-magic than did others. They nonetheless never attained a position that gave them direct authority over another clan, or another lineage, except when it was of the same clan in the same area.

Hutchins called these big rainmakers "chiefs" and in the autumn of 1925 suggested that both Mbago and Hega should be enthroned as equals to Kingalu, who was already chief of the former akidat of Mkuyuni. (Hutchins seems to have forgotten Bambarawe, possibly because he thought 


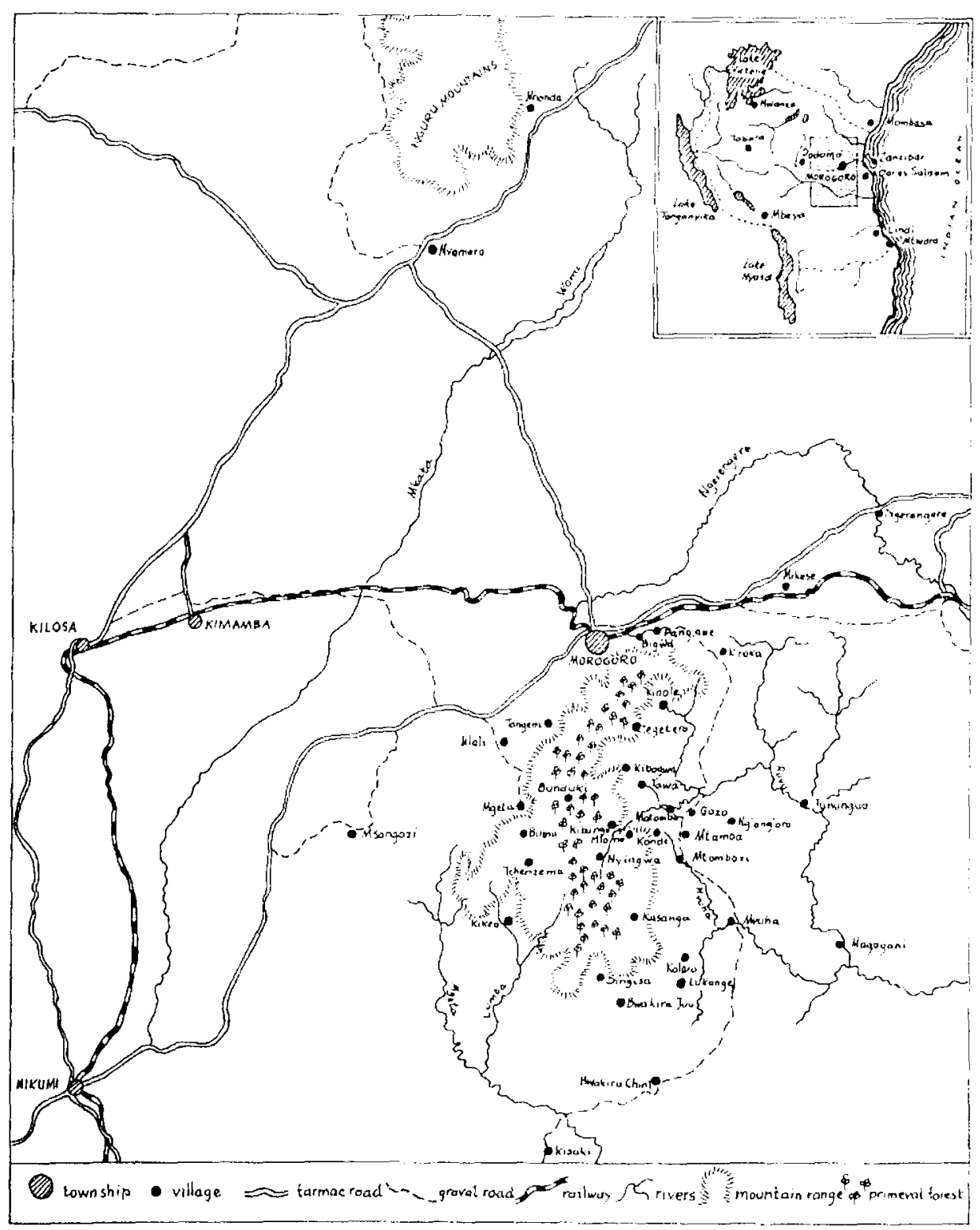

Figure 2. Uluguru Mountains and environs.

that Bambarawe no longer exercised his rainmaking functions after having become a Catholic-which was not the case.) But these influential headmen can be better understood as big men (wakubwa) who had risen to prominence by the successful manipulation of the magical, economic, and military sources at their command. Some of them drew on resources from outside the mountains: Mbago MwanaMatolola and Kingalu Fimbombili are on record as using their traffic with the coastal Arabs to their advantage (Mzuanda 1958:27-31; Wendelini n.d.:43-44). ${ }^{33}$ Two different stories of the original settlement of Kinole area by the first Kingalu, 
however, will show what indigenous political strategies were available to Waluguru beyond lukolo discourse.

The two versions of the story share the same outline: Mleke MwanaMsumi and his sister Mkirindila were on their way from the Nyingwa-Kibungo area to look for new land in the Kinole area (see Figure 2). ${ }^{34}$ When they camped in that area, they were discovered by the local leader, Magoma, who was of a different clan. ${ }^{35}$ Magoma immediately suspected evil intentions and went out to meet Mleke with a force. Mleke, however, managed to convince him of his peaceful intentions, they became friends, and, while Mleke got a piece of land from Magoma, Magoma married Mkirindila. Mkirindila, however, was asked by Mleke to spy on Magoma. When Mleke's army was ready and he knew all secrets of Magoma, he treacherously attacked him and drove him from Kinole. Subsequently, Mleke changed his name to Kingalungalu, the fickle one, which was later shortened to Kingalu. Kingalu continued with warfare, attacking his brother or, alternatively, his father, who still lived in the Nyingwa-Kibungo area, but he was killed, also through treason, and his people were driven back to Kinole.

The meeting between Mleke and Magoma is of great interest because the two versions of the story differ considerably. In the Kibungo version, told to an African priest (see Mzuanda 1958) by people oi that area, Mleke says he wants to be friends and Magoma naively believes him and gives him a piece of land. Only after two years does Magoma decide to take a Mlambena (daughter of the Bena clan, like Mkirindila) as his wife..$^{36}$ In the other version, which James Brain got from one of the sons of Kingalu Mwanarubela at Kinole, the interaction is pictured rather differently. On his arrival at Mleke's camp, Magoma first inquires whether he has evil intentions, and, after Mleke's denial, spends some time talking. The next day he returns and is given maize beer-a considerable gift, hecause beer (pombe) has a pivotal role in ritual and social action. The story emphasizes that to Magoma and his people maize beer is an innovation. Magoma spends the night at Mleke's camp and during the next day sees Mleke's sister Mkirindila and asks for her hand in marriage. Mleke consents (another gift); after staying for some time with Mleke, Magoma leaves with his bride. Just before their departure, Mleke instructs his sister to spy on Magoma.

Significantly, in the Kibungo version (which derived from a group hostile to the imperial claims of Kingalu and his supporters), Magoma is an innocent who gives a gift and gets treason in return. In the Kinole version, it is Mleke who starts giving (first a novel way of preparing beer, then his sister) and Magoma responds by allowing him to stay on his land. Like a good son-in-law, Magoma stays with Mleke-uxorilocally-but then anomalously departs for his own home. It is only when Magoma departs with his bride that Mleke starts his treason. Moreover, in the Kinole version Kingalungalu starts making war on his brother only after the latter had insulted his sister's son's wives (who are, nominally, Kingalu's wives), while, in the Kibungo version, he makes war on his father, headman of Kibungo, without any reason-an unforgivable act of disrespect.

Essential to an understanding of Luguru political process is that both versions of this story relate a form of contact between members of different clans. The clans have no necessary relationship with each other, and it is significant that in this interclan context Kingalungalu, the fickle one, becomes a nom de guerre. Brain rightly remarks that among Waluguru cunning (ujanja) is something to be admired (1971:831). ${ }^{37}$ Although someone who gains his objectives by cunning alone does not deserve respect, many Waluguru are conscious that, in political realms where relationships of descent and respect no longer provide a more or less sufficient check on individual initiative, no one is to be trusted.

F. G. Bailey's treacherous "clever leader" (1969:61), however, is not simply the "norm" for Luguru politics outside the politics organized by the discourse on clans and lineages. There are many examples of different clans that coexist peacefully. Lukolo discourse could also serve to co-opt new members into a body politic: the majority of landholders in the valley of Konde had 
once been adopted by the mwenye saku, Lwango, as nominal sister's sons, perhaps to strengthen the Mwenda clan against attacks by its powerful neighbor, Bambarawe. ${ }^{38}$ Moreover, it would be naive to think that the politics of give-and-take, threat, and treason were restricted to relationships between people who did not share a litıe of descent: members of the same clan, (but different lineages) or members of the same lineage, al so had to consider git giving, magical threat, or physical power among themselves. If such internal quarrels were usually addressed in the idiom of witchcraft, that idiom itself shaded imperceptibly into the idiom of war- and rain-magic of interclan rivalry (Pels, in press: ch. 6). The difference between intraclan and interclan politics arose mainly from the dominance established by elders-men in particular-in education, initiation, and marriage negotiations. This dominance found its most concentrated expression in the practices of initiation specific to a certain group, and it was legitimated by lukolo discourse.

Thus we can distinguish two registers of Luguru political discourse: one characterized by the concepts of lukolo authority, and another that allowed for the Machiavellian machinations of big men. As the story of Kingalu I makes clear, the latter register was also discursively regulated (by the right ways of giving a gift, of granting hospitality, and of marriage exchange) although it was not stabilized by the magical sources of clan and lineage authority that underpinned the position of a landholder-which, if violated, would incur the wrath of the ancestors to the detriment of the whole hamlet. Beyond the influence of ancestral authority, no enduring vertical relationships were maintained, and those landholders who managed to rise above their fellows can be designated as "big men." Their superior status was tirmly tied to their personal initiative and could not easily be objectified to such an extent that it could be passed on to their successors. Ironically, the British directed most of their eiforts at introducing hereditary chieiship? into the latter sphere, where Luguru ideas about hereditary power did not apply.

\section{the safari method and the pidginization of Luguru politics}

In order to assess the interaction of the languages of indirect rule and Luguru politics, it is insufficient to concentrate on the texts of Luguru administrative ethnography alone (Pels 1994). To identify the latter as a pidgin in relation to its substrate and superstrate languages, one must focus on the practice of the production of administrative knowledge about Uluguru. What can be called a "safari method" underlay both major efforts in the administrative ethnography of Uluguru, Hutchins's "Tribal History and Legends," and F. J. E. Bagshawe's "Land Development Survey Report." Fortunately, Bagshawe kept a diary, recording his tour of Uluguru in minute detail. ${ }^{39}$ The tour was a common practice of all Cameron's officers, who administered a district while traveling through it, calling together a council meeting (baraza), and, when finished, packing up and leaving for the next rural center. For ethnographic work, the administrators simply had to invert the council meeting: during a normal meeting, the Officer spoke and the Africans (chiefs, subchiefs, headmen) asked questions or nodded assent, while during ethnographic study it was the officer who asked questions and nodded assent when and where the answers to his questions confirmed what he wanted to hear.

A council meeting proceeded in Swahili, not Kiluguru; thus, to be able to speak Swahili was a sine qua non for administrative office, a criterion not explicitly recognized by the Britsish. Despite any hereditary claim to authority, widespread popularity, or proven competency, a headman who spoke only Kiluguru could not get a government job. Like Kingalu Mwanarubela, Bagshawe's main conversation partner in the following account, Waluguru who were successiul in government jobs were usually former servants of Europeans, proficient in Swahili, and inured to a routine of command and obedience. When Bagshawe set off on his tour in December 1929, his assignment was to find out whether, given the nature of Luguru land tenure, land could be alienated and sold to nonnative settlers. Moreover, he wanted to check the ethnographic 


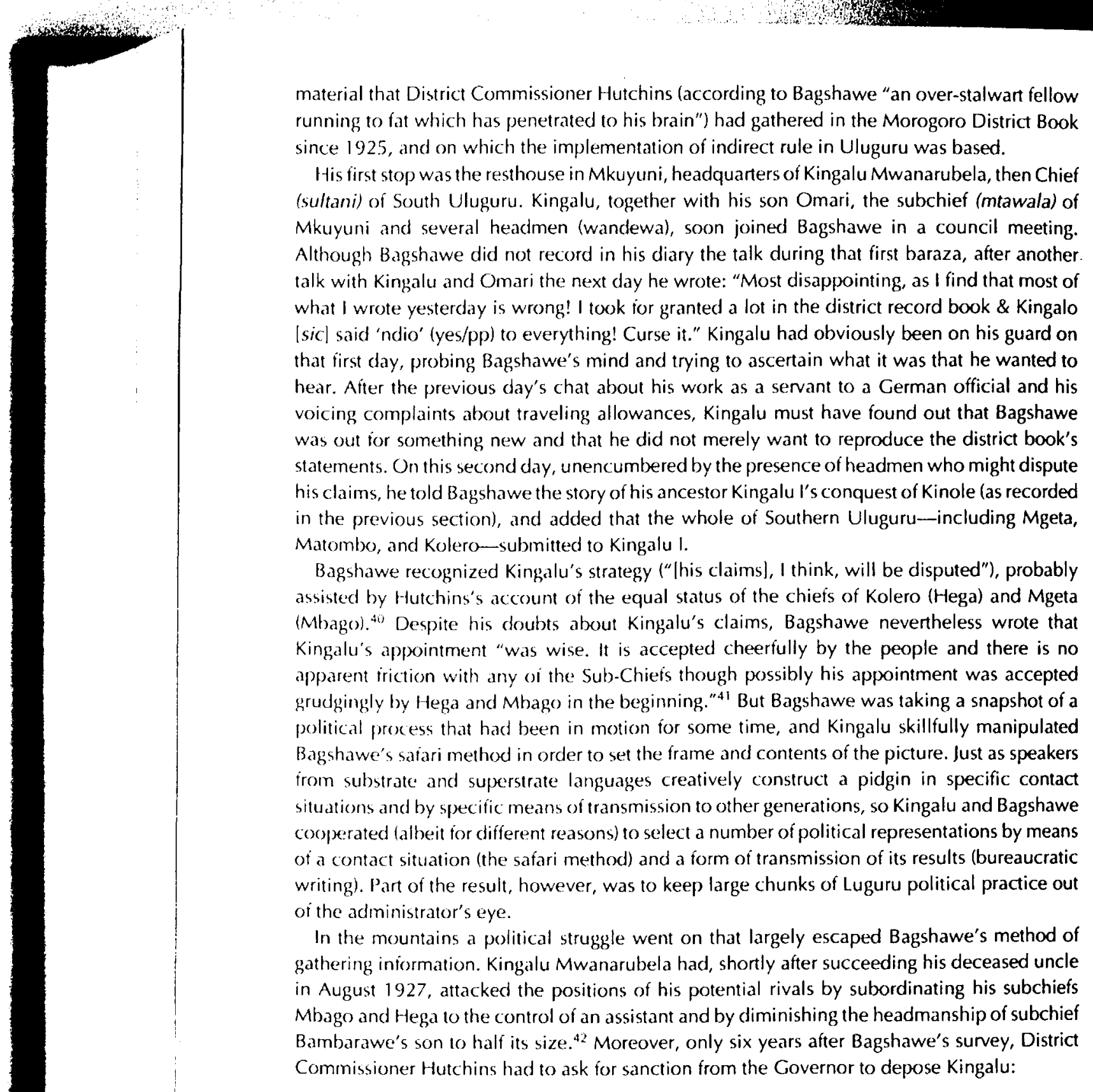

material that District Commissioner Hutchins (according to Bagshawe "an over-stalwart fellow running to fat which has penetrated to his brain") had gathered in the Morogoro District Book since 1925, and on which the implementation of indirect rule in Uluguru was based.

His first stop was the resthouse in Mkuyuni, headquarters of Kingalu Mwanarubela, then Chief (sultani) of South Uluguru. Kingalu, together with his son Omari, the subchief (mtawala) of Mkuyuni and several headmen (wandewa), soon joined Bagshawe in a council meeting. Although Bagshawe did not record in his diary the talk during that first baraza, after another alk with Kingalu and Omari the next day he wrote: "Most disappointing, as I find that most of t I wrote yesterday is wrong! I took for uranted a lot in the district record book \& Kingalo voicing complaints about traveling allowances, Kingalu must have found out that Bagshawe was out for something new and that he did not merely want to reproduce the district book's statements. On this second day, unencumbered by the presence of headmen who might dispute his claims, he told Bagshawe the story of his ancestor Kingalu l's conquest of Kinole (as recorded the previous section), and added that the whole of Southern Uluguru-including Mgeta, (Mbago). ${ }^{4 i)}$ Despite his doubts about Kingalu's claims, Bagshawe nevertheless wrote that Kingalu's appointment "was wise. It is accepted cheerfully by the people and there is no apparent iriction with any of the Sub-Chieis though possibly his appointment was accepted grudgingly by Hega and Mbago in the beginning." ${ }^{41}$ But Bagshawe was taking a snapshot of a political process that had been in motion for some time, and Kingalu skillfully manipulated Bagshawe's saiarimethod in inder to set the frame and contents of the picture. Just as speakers cooperated a beit for difterent reasons to select a number of political representations by means of a contact situation (the safari method) and a form of transmission of its results (bureaucratic writing). Part of the result, however, was to keep large chunks of Luguru political practice out of the administrator's eye.

In the mountains a political struggle went on that largely escaped Bagshawe's method of gathering information. Kingalu Mwanarubela had shortly after succeeding his deceased uncle in August 1927, attacked the positions of his potential rivals by subordinating his subchiefs Mbago and Hega to the control of an assistant and by diminishing the headmanship of subchie Commissioner Hutchins had to ask for sanction from the Governor to depose Kingalu:

The Chief is greedy and unscrupulous and the sole reason why his subjects have accepted his abuses without complaint for so long is because of the power he holds over them as a rain-doctor, which practice he has never abandoned. Whilst litle could be definitely proved against him, whispers of his malpractices are becoming increasingly audible, and I have little doubt but that the majority of his subjects will breathe a sigh of relief when his reign comes to an end. ${ }^{43}$

The Governor agreed, and the process of assessing the administrative capacities of Kingalu's heir, his nephew Gungurugwa, and the claims of his rivals was started. Kingalu's subchiefs were very diffident about having to express their preferences, and, although they chose Cungurugwa, Hutchins could not but feel that it was not "in agreement with the wishes of the majority." Gungurugwa, on the other hand, knew that, when appointed, he would be no more than a iigurehead for his deposed uncle. ${ }^{44}$ Hutchins proposed to his Provincial Commissioner to amalgamate North and South Uluguru under the Chief of North Uluguru, Muhina Coso Kingo, 
and went on leave. The Provincial Commissioner encountered the same confusion in trying to assess who really represented the wishes of the majority, and, after a number of unsatisfactory and mutually contradicting council meetings, the majority of subchiefs and headmen expressed themselves in favor of the government's choice; in due time Kingo became the first Chief of the whole of Uluguru. ${ }^{45}$

The British attempts to second-guess at the whispers of the majority, and the hesitation of Waluguru to choose between "hereditary" claims to office and the wishes of the government, indicate an element of the substrate or subaltern politics that helped to construct-yet did not appear in-administrative ethnography. Waluguru often told me of the necessity of having a "cool heart" (moyo baridi) in dealing with other people. A responsible leader had been taught to suppress moto ("fire," but also "anger," "desire," or "aggression"), because it could never lead to agreement in relations with others, or, more significant, to harmony with the ancestors (mizimu), who prefer coolness, tranquility, and shade to sun and exertion. Contradicting another person was a gesture of moto that befitted neither leaders nor their subordinates. Kingalu, Bambarawe, Mbago, and Hega embodied some of the most important spirits in Eastern Uluguru and could anger them-their source of power and authority-in contradicting each other. They might provoke a showdown of power, unleashing magical forces that none of them wanted to confront. ${ }^{46}$ And, of course, it was neither necessary nor advisable to unveil one's political strategies for a chief or his white superior-they were better kept to oneself. We only have to think of Kingalu saying "ndio" to everything Bagshawe suggested on the first day of the visit to understand how elementary this reticence was in Luguru politics.

Kingalu adroitly manipulated this tendency not to complain about one's leader except behind his back: he hardly left Bagshawe's side during his survey safari. ${ }^{47}$ Conversely, the superstrate language of representation guaranteed that Bagshawe never tried to speak to Kingalu's subordinates in Kingalu's absence, despite the fact that Kingalu himself had shown how Waluguru guarded their statements in the presence of superiors. Issues of hereditary representation constituted the council meetings: at a later baraza, Bagshawe discussed the subchiefship of Kasanga, in the presence of the Kingalu, the Matombo subchief Bambarawe, some headmen. and several candidates for the post. Headmen not appointed by the British were automatically excluded. More important, there were no women present, despite the fact that the leading women of a lineage exerted formal political power beyond the selection of suitable successors to a lineage headmanship. The former subchief of Kasanga, Chambandewa, was a son of the prewar Hega, and Kingalu had taken hereditary, matrilineal succession as an excuse to replace him with his own candidate. The latter, however, was soon deposed for embezzlement, and Bagshawe had to resolve who was to succeed him, sandwiched as he was between Kingalu's manipulation of "hereditary" succession and Chambandewa's attempts to resist it. In this context, it is significant that Bagshawe had no time for Chambandewa when the latter tried on a later occasion to talk to him alone: Chambandewa was no longer "representative." Thus Luguru avoidance of moto and British ideas of representation combined to pidginize Luguru politics.

Kingalu was absent from Bagshawe's council meetings on only one other occasion, and this may indicate another way in which a discourse of representation pidginized Luguru politics. Bagshawe sent Kingalu to Morogoro to settle the boundaries of Northern and Southern Uluguru with Kingo, chief of the North, and went alone to Matombo, where he had a long talk with Bambarawe and his wandewa:

[Bambarawe] does not claim that the ancient Mbambalawe' $s^{48}$ were "over" the local Wandewa, but they were respected \& were rain and war doctors, his uncle, especially, having defeated Wambunga invaders. All Wandewa ruled their clans in ordinary affairs independently. The Germans marle his uncle chiet; he says that if anyone was chief in pre-German days, it was Kingalo [sic| No one has replaced his (Bambarawe's/pp) family as rain-makers since he became a Christian. ${ }^{49}$ 


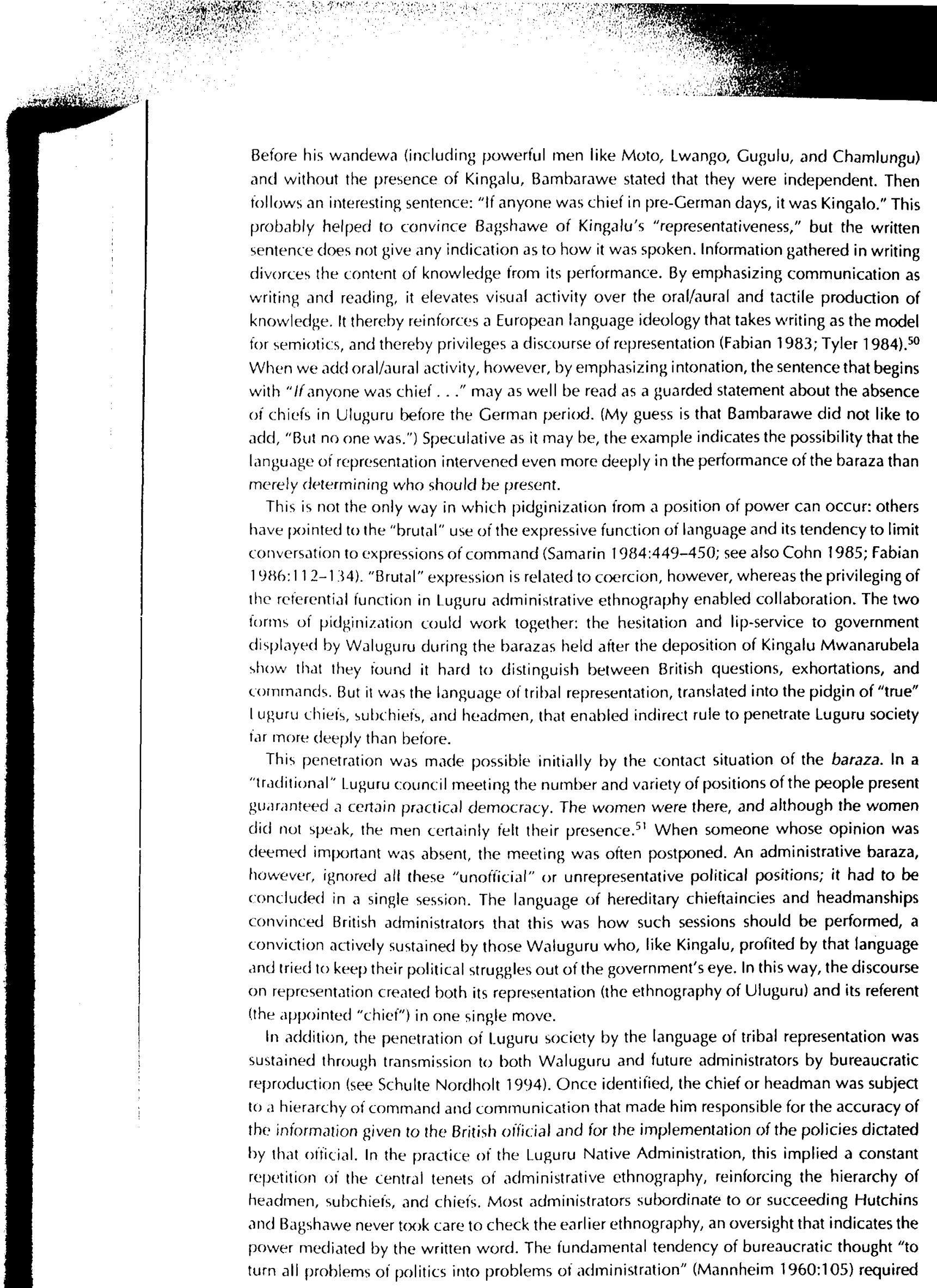

Before his wandewa (including powerful men like Moto, Lwango, Gugulu, and Chamlungu) and without the presence of Kingalu, Bambarawe stated that they were independent. Then follows an interesting sentence: "If anyone was chief in pre-German days, it was Kingalo." This probably helped to convince Bagshawe of Kingalu's "representativeness," but the written sentence does not give any indication as to how it was spoken. Information gathered in writing divorces the content of knowledge from its performance. By emphasizing communication as writing and reading, it elevates visual activity over the oral/aural and tactile production of knowledge. It thereby reinforces a European language ideology that takes writing as the model for semiotics, and thereby privileges a discourse of representation (Fabian 1983; Tyler 1984). ${ }^{50}$ When we add oral/aural activity, however, by emphasizing intonation, the sentence that begins with "If anyone was chief ..." may as well be read as a guarded statement about the absence of chiefs in Uluguru before the German period. (My guess is that Bambarawe did not like to add, "But no one was.") Speculative as it may be, the example indicates the possibility that the language of representation intervened even more deeply in the performance of the baraza than Thely determining who should be present. conversation to expressions of command (Samarin 1984:449-450; see also Cohn 1985; Fabian 1986:112-134). "Brutal" expression is related to coercion, however, whereas the privileging of the referential function in Luguru administrative ethnography enabled collaboration. The two iorms of pidginization could work together: the hesitation and lip-service to government displayed by Waluguru during the barazas held after the deposition of Kingalu Mwanarubela show that they iound it hard to distinguish between British questions, exhortations, and commands. But it was the language of tribal representation, translated into the pidgin of "rue" I uguru chieis, subchiets, and headmen, that enabled indirect rule to penetrate Luguru society ar more deeply than before.

This penetration was made possible initially by the cont did nol speak, the men certainly felt their presence. ${ }^{51}$ When someone whose opinion was deemed important was absent, the meeting was often postponed. An administrative baraza, hever, ignored all these "unofficial" or unrepresentative political positions; it had to be convinced British administrators that this was how such sessions should be performed, a conviction actively sustained by those Waluguru who, like Kingalu, profited by that language and tried to keep their political struggles out of the government's eye. In this way, the discourse on representation created both its representation (the ethnography of Uluguru) and its referent he appointed "chief") in one single move.

In addition, the penetration of l.uguru society by the language of tribal representation was sustained through transmission to both Waluguru and future administrators by bureaucratic reproduction (see Schulte Nordholt 1994). Once identified, the chief or headman was subject os a hierarchy of command and communication that made him responsible for the accuracy of he information given to the British oflicial and for the implementation of the policies dictated that official. In the practice of the Luguru Native Administration, this implied a constant or the central tenets of administrative ethnography, reinforcing the hierarchy of power mediated by the written word. The fundamental tendency of bureaucratic thought "to turn all problems of politics into problems of administration" (Mannheim 1960:105) required 
stable representations, which were provided by both the written reifications of administrative ethnography and the "chief" as the personified, nonarbitrary sign of Luguru authority.

The stability of this administrative pidgin was nevertheless an illusion, if only because its contents were interpreted by different groups in difierent ways. While Bagshawe seemed to think of the appointed chiefs and headmen as representative of their people lowing to either the laws of hereditary succession or a simple absence of complaints), subordinate Waluguru probably thought of the chief as the employee of the government. The stability of "true" or legitimate political representation as perceived by British administrators, might, instead, be a stability based on fear of the powerful, for, as I was told in 1990, "we should be arraid of the government" (tuogope serikali). That brings us, in conclusion, to the systematic instability of indirect rule.

\section{the paradoxes of pidgin politics}

Indirect rule in Uluguru was characterized by a strong tendency toward the reitication of ethnographic representation along legalistic and bureaucratic lines. But no bureaucracy can keep out politics by decree alone, and this was further complicated by the paradoxes and contradictions existing among and within substrate, superstrate, and pidgin political discourses. Above, I have already noted the tension between the standards of hereditary succession and those of "good government" within administrative anthropology, as well as the tension within Luguru political discourse between lukolo discourse and the real $m$ of the exchange of violence, magic, and gifts. In conclusion, I would like to consider how these tensions reappeared in the practical implementation of pidgin politics, which created a proliferation of political possibilities comparable in effect to the addition of a pidgin to the linguistic world of both substrate and superstrate languages.

As I have demonstrated, the implementation of indirect rule in Uluguru was based, on the one hand, on the invented offices of chief and subchief (which reified the fluid and transitory "big man" positions of Kingalu, Hega, Bamabarawe, and Mbago on the grounds of a theory of political evolution through war-and rainmaking powers) and on the other on the incorporation of selected Luguru landholders at a lower level of the administration. The instability of the standards by which appointments were made is evident from the fact that the 1.5 headmen appointed in the Matombo area in 1926 had been increased to 21 in 1947." The appointed headmen often ruled an area much larger than their previous sphere of influence, partly because headmen who could not speak Swahili were ineligible for office. Moreover, many Waluguru tried to keep pidgin politics - the representations of administrative ethnography-at a distance because they were afraid to see their leader, who had to protect clan and land iertility through a tenuous relationship with his ancestors, compromised by direct subordination to the white man. Often, sons or cousins of wenye saku were appointed as headmen in the place of their fathers or uncles. In some places, a rival managed to stage a coup) (like Moto-the name is significant-who displaced his nominal uncle Lwango in Konde). In others, a former jumbe (headman under German rule) who had settled in the area as a Christian teacher managed to retain his post (like Marie Pauli in Tawa) with no hereditary rights whatsoever. Bambarawe joined Kiswira (his own valley) with Gozo into one single headmanship and gave it to his son, who remained in office until 1928, when Bambarawe's rival Mgombelwa got Gozo back with Kingalu's help. The seemingly stable representations of Luguru authority by the British thus often merely covered a series of desperate political fights.

But this stability was also threatened from within the discourse of administrative anthropology. Its standard of hereditary succession was the core of its theory of tribal representation and topped the hierarchy of standards of government. As I have shown, however, hereditary succession had to be weighed against the suitability of the candidate and the will of the people. In practice this 


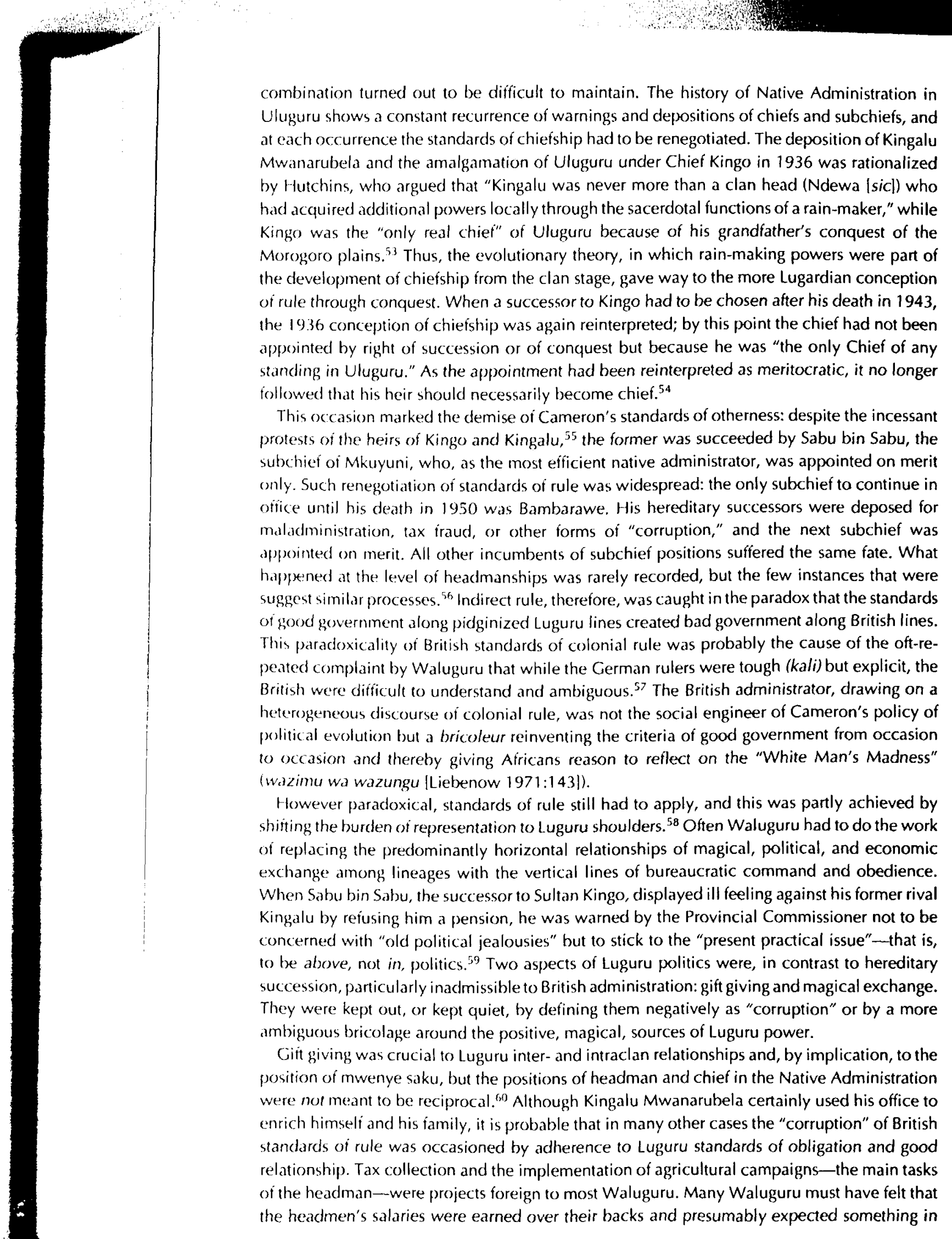


recompense. This may have been more difficult, in lukolo terms, for the legitimate landholder than for a usurper or alien because the former would have to consider all his existing obligations as well as what the British asked of him. If the salary of an incumbent subchief without hereditary rights was, in one case, surrendered to the rightful mwenye saku, ${ }^{61}$ we can presume that more of the spoils of government position were divided in this way. The fact that after 1945 "corruption" became scarcer may not mean that it disappeared but merely that Waluguru had accommodated to British desires about the public performance of government servants.

Magical powers were even more ambiguous for indirect rule. Steven Feierman has shown how persistent and necessary rain-making powers were in Usambara politics (1990). In Uluguru, Kingalu's status as a rain doctor was first an (evolutionist) argument for, and then against, his appointment to the chiefship. Uganga ("medicine" or "benevolent magic") was close to witchcraft and not admissible to the British government; yet it was an important ingredient of Luguru power relationships (as Hutchins's comments on Kingalu's rainmaking capacities make clear). The British were forced to deal with its ramifications but preferred to do so offstage. For instance, the District Commissioner asked the African mayor of Morogoro to accompany sultan Sabu when the latter toured Uluguru, because the mayor did not believe in magic and could therefore strengthen the morale of his friend who feared the magic of his political rivals. ${ }^{62}$ Fields (1982) has shown to what extent British officials themselves were implicated in the practice of magic, a practice to which their disbelief was peripheral.

Judging from the memoirs of an Agricultural Officer, the number of times British officials went to a mganga (witch doctor) for divination to find a thief or for medicine to cure a mysterious disease that did not respond to European treatment was considerable. ${ }^{63}$ Most of the work in the realm of unseen political powers, however, had to be done by Africans themselves, and in particular by traveling medicine hunters. Administrators' initial fear that these large-scale political movements might imply a recurrence of the Maji Maji rebellion of $1905-06$ was overcome by the early 1940 s and laid to rest by labeling them "religious." 64 In this way, political magic could continue to function under indirect rule, perhaps bothering Christian missionaries but causing little practical anxiety to British administrators (Pels, in press: ch. 6).

conclusion

Thus, while I agree with Timothy Mitchell that a European discourse of representation created an "appearance of order" that tried to mask its own authorship oi, and authority over, a "Luguru tribe," I hope to have shown that it was not an "order that works by appearance" (Mitchell 1991:60; emphasis added). While administrative ethnography and its bureaucratic reproduction may sometimes have given British administrators the feeling that they could absent themselves from political struggle, they had to work hard to keep up the appearance of "indirect" rule, and they did not succeed without regularly subverting the "tribal" representation of administrative anthropology by their evolutionist notions about progress toward good government. Conversely, many Waluguru attempted to defend their existing political routines against the encroachment of the written representations and embodied representatives of administrative ethnography. For both parties, administrative ethnography remained a second language, a pidgin that could not carry the full range of political possibilities of the discursive practices from which it was derived but that nevertheless complicated and enriched these possibilities. In the end, the paradoxes and contradictions of indirect rule led to a grave political crisis in the 1950 s when the Luguru Native Administration was attacked directly by those it claimed to "represent" (see Brain 1979). Shortly afterward, Luguru political life was swept into the channel of African nationalism, a "shift to the superstrate" of representative democracy that it is tempting to describe as a political form of "creolization" (cf. Hannerz 1987; Jourdan 1991:202). But that story must be addressed elsewhere. 


\section{notes}

Acknowledgments. Research for this article was supported by the Amsterdam School for Social Scientific Research and by a grant from the Netherlands Foundation for the Advancement of Tropical Research (WOIRO). I thank Johannes Fabian for his comments and editorial work on an earlier version, and three anonymous reviewers of the American Ethnologist, and the previous editor, Don Brenneis, for their valuable and productive comments. Mr. H. Streefkerk kindly drew the map, a task he has performed for so many other Dutch anthropologists.

1. The archival sources referenced in this article are as follows:

CS-Chief Secretary to the Governor of Tanganyika

DAM--Diocesan Archives Morogoro, in the Bishop House, Morogoro, Tanzania

DC-Districl Commissioner of the Tanganyikan Administration

PC-Provincial Commissioner of the Tanganyikan Administration

KH-Rhodes House Library, Oxford, United Kingdom

TNA-Tanzania National Archives, Dar es Salaam, Tanzania. The "Morogoro District Book" is accessible on microvilm no. 19

UDSM-University or Dar es Salaam library, Dar es Salaam, Tanzania

2. A similar emphasis on true and false representation can be identified in both critical and apologetic studies of colonial missions (Pels, in press: ch. 1).

3. See Hirschkind 1991:285. See also Mitchell's treatment of Bourdieu's account of the Kabyle house (Bourdieu 1977:90-91), which makes it into the "other's" play of difference and ignores it was originally meant as an illustration of a general, rather than culturally specific, theory of practice (Mitchell 1991:48-53).

4. John lliffe discusses the mutual implication of colonizers and colonized in indirect rule politics, but his territory-wide focus prevents him from studying its mediations in detail (1979:318-341). Feierman provides one of the few subtle analyses of the colonized's reception of indirect rule, but his account of the British is disappointing (1990:134-137).

5. For an elaboration of these terms, see Pels 1994; Pels and Salemink 1994; and Schulte Nordholl 1994.

6. L. ugard's main contribution to Tanganyikan indirect rule was to support, after his return to England in 1918, missionary activists who formulated the principle of colonial trusteeship in terms of the "primacy of Afric an interests" in opposition to (predominantly Kenyan and South African) settler polities, a principle on which Cameron and his Labour allies drew during their own struggles in the late 1920s (Bennet 1960:357; Cell 1989: Gailey 1974:40).

7. Clifiord was a good researcher and an expert on the Malay language. He introduced the post of secrelary of native affiars 10 the Nigerian administration, an innovation that Cameron also adopted in Tanganyika to coordinate ethnography (Gailey 1974:49). Clifford wrote in 1922:

knowledge, sure and unerring knowledge of the people, of their character, of their point of view, of their customs, habits, modes of thought, is needed as the solid foundation upon which alone really sound political work can be reared up; and this has to be garnered slowly, patiently, painfully, little by fittle. las quoted in Kirk-Greene 1965:179]

8. Anthropological professionalization in Britain was first propagated by both academics and former Indian administrators (see Kuklick 1991:196-199; Pels and Salemink 1994). The debate between Malinowski and Cameron's Chiei Secretary, Philip Mitchell, shows the potential tension between the two groups (Malinowski 1930; Mitchell 1930). While both drew on similar exemplars, professional anthropology was more influenced by the zoological field expedition and the psychological laboratory (Stocking 1983), while administrative anthropology's "field" was a bricolage of public school playing field (Heussler 1963), the hunter's safari (Mackenzie 1987), and the amateur naturalist's scientific interests (Pels 1995). For an admirable description oí how these different iniluences made a late colonial anthropological "field," see Schumaker 1993.

9. Cameron claimed that this problem convinced him to institute indirect rule (Gailey 1974:39l; also Ingham 1965:552, 571). Dundas, however, wrote that Cameron had already decided upon this policy before arriving in Tanganyika (Dundas 1955:132).

10. As District Commissioner of Kilimanjaro, Dundas persuaded Wachagga to grow coffee (Ingham 1965:5.56) and was instrumental in forming the Kilimanjaro Native Planters Union. In due time Dundas became "Wasahuye-O-Wachagga," an elder of the Chagga; he returned the favor by publishing a history of the Wachagga ior the Wachagga, a highly unusual gesture at the time (Dundas 1955:117-128).

11. Compare Cameron's 1934 reformulation of Lugard's "cardinal principle" of indirect rule to the original (Cameron as quoted in Kirk-Greene 1965:193; Lugard 1970|1919]:296). This reformulation was a product of Cameron's later years, and less dogmatic on the primacy of chiefs than he had been in his Tanganyikan dispatches (see Cameron 1937).

12. "There is a great deal of work to be accomplished in the way of ascertaining the history of the tribe afiected, their iraditional organization, their iraditional rulers, their proper boundaries, etc." (TNA 7777: CS to All Senior Commissioners and Administrative Ofificers, 5-18-95). This was a form of colonial empiricism that had rather different, because historicizing, consequences than an earlier, British Indian, form (see Ludden 1993). Among the dissidents, F. J. E. Bagshawe thought that Western influence had been present ior too long to be erased from the minds of the Africans, while Dundas (who knew the German records better than Cameron) said that the absence of chiefs was a good reason for the institution of the akidas (RH 
s.285: Bagshawe diary, 8-24-27; TNA 7777: Dundas to Scoll, 7-3-25). Cameron repeatedly opposed the view that the Germans had also used some form of indirect rule (TNA 1 1601/: Oldham lo Cameron, 2-27-29. Mitchell to CS, 4-5-29, Kastl to Scott, 10-9-28).

13. TNA 7777: Note for Officer Commanding Troops on Native Administration by C. C. Dundas, probabily 1927.

14. Cameron's 1934 comments on the Hausa-Fulani chiefs installed by Lugard show that he thought this medieval stage, which emphasized conquest rather than legitimacy, should be skipped by political engineering (as quoted in Kirk-Greene 1965:193, 195, 205-206).

15. TNA 7777: "Tanganyika Territory. Native Administration," by D. Cameron, 1-3-27; CS 10 all Senior Commissioners and Administrative Officers, 5-18-25; Minute Cameron, no. 28, 6-25-25; Contidential Circular, Native Administration, 7-16-25; INA 1733/6: Tanganyika Territory Annual Report, 1925; INA 61/6: Instruction on Native Administration, in Dundas to All PCs, 8-20-26.

16. Cameron, in Kirk-Greene (1965:193); TNA 61/6: Dundas to All PCs, 2-23-26; TNA 7777: Dundas to Scott, 7-3-25, Secretary of State for the Colonies to Cameron, 9-16-25, CS 10 all Senior Commissioners and Administrative Officers, 11-26-25

17. Therefore, an alien "native agent" could not try the cases al a Native Court (TNA 7777: Minute Cameron no. 28, 6-25-25; on "extra-tribal" forms, see TNA 7777: Secretary of State for the Colonies to Cameron, 9-16-25).

18. Compare with Public School ideology (see Heussler 1963:95 on the inadvisability of elections in Tanganyika; TNA 61/6: Dundas to All PCs, 2-23-26). Cameron relused to have Africans on the Legislative Council because he felt that none of the chiers were educated enough to participate and that no educated African sufficiently represented his people (Gailey 1974:47).

19. TNA 7777: Minute Cameron no. 28, 6-25-25; Confidential Circular on Native Administration, 7-16-25.

20. The "wili of the people" seems to have been an addition typical to Uundas, who drafted the circular (C. Dundas, Draft Circular no. 50, TNA 7790: 7-9-25).

21. The third pillar of native administration, the native treasuries the first and second being the native authority and the native court), was more clearly propagandistic: it should create the impression that people paid for their own native authority, with only "minor intervention" by the Officer to prevent waste and corruption. Most Waluguru seem to have thought, however, that the British simply took most of the loot (TNA 7777: Confidential Circular on Native Administration, 7-16-25; TNA 1733/6: Tanganyika Territory Annual Report, 1926; Mzee Paulo Josefu Mgundukano, Konde, 11-7-89).

22. See below land TNA, Morogoro District Book: "The Akida System," by f.. F. Hutchins, 1930; "I ribal History and Legends, Luguru and Kami Tribe," by E. Hutchins; TNA 7777: CS to Administrative Ofificer Morogoro, 8-7-25; TNA 1733/13: Morogoro Annual Report, 1925; TNA 7777: Dundas to Scoll. 7-3-25) Graham mentions that Mitchell, as secrelary of nalive affairs, decided upon the (faully) constitution of the Njombe Native Authorities in 1926, which implied bypassing CS Dundas and PC Bagshawe (1976:5). Something similar may have happened in Morogoro.

23. Dundas was made CS (and succeeded by Mitchell as secrelary of native aifairs), but under Cameron (who did most work himseln that post did not carry the weight of the formally lesser post of secretary of native affairs. In 1928, there was animosity between Cameron and Dundas (RH s.287: Bagshawe diary 8-10-28). Contrary to Philip Mitchell, Cameron's favorite, Dundas was not promoted after his lour as CS and, while Mitchell became governor of Uganda in 1935. Dundas had to wait until 1937 in get a minor governorship, that of the Bahamas. Dundas succeeded Mitchell in Uganda in 1940 (Gailey 1974:138-140)

24. Clans (lukolo [Kiluguru]; ukoo [Swahili]) and lineages (tombo [Kiluguru|; ziwa [Swahili]) are lox important in Luguru society to accept that we should refrain from using the term "lineage" because it does not represent folk models and because lineages do not organize "vital political or economic activities" (Kuper 1982:92; he uses the term lineage model, the "model" aspect of which he lails to explain. Kuper does not mention Peters (1967), who had formulated Kuper's doubsts about the term lineage 15 years earlier.

25. The Agricultural Department dated the settlement of Uluguru later (in 1884) 10 emphasize the speer with which soil erosion took place (TNA, Morogoro District Book: "Soil Erosion in the Uluguru Moumlains," A. H. Savile, 4-24-47). Waluguru list up to 15 successors to a lineage headmanship, which makes this unlikely. Fosbrooke, taking 20 years for one generation, arrived at 1660 as the approximate year oi entry (Young and Fosbrooke 1960:21), but ignored succession by brothers. In Kingalu's genealogy, Hutchins lister six instances of brotherly succession (TNA, Morogoro District Book: "Tribal History and Legends, Luguru and Kami Tribe"). Of the 12 Kingalus (Fosbrooke: $\mathrm{Ca} .240$ years) that could be listed in 1960, thereiore, six generations disappear (minus 120 years), which would put the time of Kingalu I at around 1840 . He. however, was a latecomer. Cory's guess (no evidence supplied) of approximately 1800 seems to be closest to the truth (UDSM: Cory Paper 430).

26. I cannot go into this history in detail. For further information see Mzuanda 1958; UDSM: Cory paper 430; Wendelini n.d.

27. INA, Morogoro District Book: "Tribal History and Legends: Luguru and Kami Tribe," by E. Hutchins.

28. The theory was shared by Cameron, Dundas, Mitchell, and others (TNA 7777: CS to Senior Commissioners Dar es Salaam, Tanga, Lindi and Adminislrative Officers Bagamoyo and Pangani, 1-26-26: Dundas to Scott, 7-3-25). It was still held in substantially the same way in the 1950s, although by them Evans-Pritchard's "segmentary lineage systems" further legitimated its theoret ical underpinnings (Young and Fosbrooke 1960:41-43). 


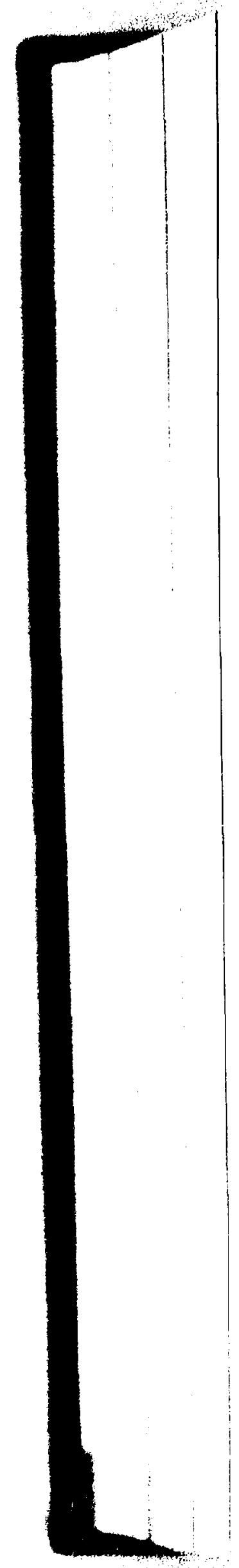

29. I will use mwenye saku for traditional authority, reserving mndewa for the neotraditional bureaucratic positions created by the British. Waluguru still follow the same usage.

30. This was the case in the valley of Konde (Mzee Mahumbo, Konde, 10-15-89).

31. An example was Shenekambi, son of Kingalu Mwanashaa (the sixth; TNA 61/1/3: Hutchins to PC 7-15-31).

32. All wenye issi and wenye saku were wenye mlunga, but not all wenye mlunga were members of the landholding clan; some earned their tilles on merit.

33. Hutchins (RH s. 1059: "The Waluguru," p. 2) mentions Mbago's tricks with a looking glass acquired in Bagamoyo. Debenham mentions an alliance, around 1860, between Kingalu I and Mwinyimkuu of Bagamoyo (TNA, Morogoro District Book: "Tribal History and Legends, Luguru and Kami Tribe"); it is more likely, however, that this is Kingalu Fimbombili IV who, according to fosbrooke, died on the coast (Young and Fosbrooke 1960:481.

34. Brain provides two versions of the story (1971), one from Mzuanda (1958:9-16) and the second, recorded by himself in Kinole. Unfortunately, his amalgamation of euhemerist, functionalist, and structuralist approaches misses the historical and dysfunctional importance of the two versions.

35. Mleke was a Mbena and a Magoma, according to the second version of the story recounted by Brain, a Mnyagatwa. The present Magoma of Tegetero calls himself Mnyani; according to Mzuanda, Wanyagatwa and Wanyani are the same (1958:78-80).

36. Mzee Magoma Mwanamtali (Tegetero, 1-16-90) said that Kingalu could not have betrayed Magoma, as he was Magoma's mjukuu (grandchild). Given the fact that Magoma married the first Kingalu's sister (who only had daughters, which meant that the name of Kingalu could only go to her grandchild), Mzee Magoma may have wanted to convince me of his seniority over Kingalu in terms of kinship discourse.

37. When I had been cheated out of a considerable sum by my first research guide, I was rather taken aback by the admiration with which my best friends alluded to him: amefaulu, "he has succeeded."

38. Mzee Mahumbo, Konde 10-15-89.

39. The Matombo Mission diary shows that DC Hutchins used the same method, using the mission as base (DAM: Matombo Diary, 11-18-25; for Bagshawe's work, TNA 18913: Uluguru Land Development Survey Report, 1931; RH s.288: Bagshawe diary).

40. RH s.288: Bagshawe Diary, Vol. XI, December 1929 - January 1930.

41. TNA 18913: Land Development Survey report, Uluguru Mounlains, 1931:4.

42. TNA 11676/: Ann. Rep. Eastern Province, 1927; TNA 11676/11: Ann. Rep. Eastern Province, 1928; TNA, Morogoro District Bcok: "Tribal History and Legends, Luguru tribe," by E. Hutchins, notes of 2-17-28 and 7-7-28; DAM: Malombo Diary, 10-27-28.

43. TNA 23841: PC Eastern Province to CS, 2-14-36

44. INA 23841: PC Eastern Province to CS, 2-14-36

45. TNA 23841: PC Eastern Province to CS, 6-30-36; PC Eastern Province to CS, 9-4-36; CS to Altorney General, 9-14-36.

46. Hutchins relates how in 1925, when Kingalu and Hega first met each other during a government baraza, they covered their iaces, because looking at each other would have meant instant death. Although Hutchins wrote that they were later persuaded to give up the "superstition," it is more likely that they reinterpreted the efficacy of their magic (RH s.1059: "The Waluguru", E. Hutchins).

47. In addition, Kingalu took the opportunity to emphasize his importance in his subordinates' eyes by being carried in a chair, heralded by drums and pipes into each location visited by Bagshawe. This earned Kingalu's retinue the name of "Alexander's Rag Time Band" from Agricultural Officer Hill.

48. This is Bagshawe's usage; most of my informants spelled it "Bambarawe." (The "l" and " $r$," different in Swahili, are nor distinguished in Kiluguru.)

49. RH s.288: Bagshawe Diary, vol. XI. January 20, 1930.

50. For an overview of language ideology, see Woolard and Schieffelin 1994, particularly the references listed under literacy (1994:65) and European ideologies of referentiality (1994:71).

51. For the political role of Luguru women see Pels in press: chapler 4.

52. Ci. Bates's remark about the proliferation of "tribes" in Tanganyika (1965:631), and Thomas's observation that the ethnographic genre, by "localizing questions" (1991:312) leads to a similar proliferation (cf. Fardon 1990; ior Luguru headmanships: Mzee Morisi Martini, Kiswira, 8-14-89; Mzee Zongera, Mtamba, 2-8-90; TNA 31347: Page-Jones to CS, 5-9-47).

53. TNA 23841: Hutchins to PC Eastern Province, 3-19-36.

54. TNA, Morogoro District Book: "The appointment of Mzee Sabu as Sultan of Uluguru," by D.S. O'Callaghan, 5-9-44.

55. In this they kept drawing on the standard of hereditary office, often by claiming the example of the British royal family (see Feierman 1990:135; Ranger 1980; TNA 26/220/II, passim).

56. For subchiefs: TNA, Morogoro District Book: passim; an example of successive headmen is the Mgombelwa's lineage in Kisem: TNA 26/220/It: passim.

57. For the Cermans, in the succincl words of Chief Patrick Kunambi's father, "black was black and white was white" (Patrick Kunambi, Dar es Salaam, 4-12-89).

58. The expression is borrowed from Tagg (1988).

59. The missionary (tto Raum (supported by Charles Dundas) made a similar observation in Uchagga: he said that a salary made a chief independent of the horizontal obligations maintained by a politics of tribute. Philip Mitchell dismissed the issue by saying he did "not understand the fuss" (TNA 11601/: Dundas 

Fields, Karen

1982 Political Contingencies of Witchcraft in Colonial Central Africa: Culture and State in Marxist Theory. Canddian Journal of Airican Studies 16:567-593.

1985 Revival and Rebellion in Central Africa. Princeton, NJ: Princeton University Press.

Flint, John E.

1978 Frederick Lugard: The Making of an Autocrat (1858-1943). In African Proconculs: European Governors in Airica. Lewis Gann and Peter Duignan, eds. Pp. 290-312. New York: Free Press.

Fortes, Meyer, and E. E. Evans-Pritchard

1940 Introduction. In African Political Systems. Meyer Fortes and E. E. Evans-Pritchard, eds. Pp. 1-23. London: Oxiord University Press.

Gailey, Harry A.

1974 Sir Donald Cameron: Colonial Governor. Stanford, CA: Hoover Institution Press.

Graham, John D.

1976 Indired Rule: The Establishment of "Chiefs" and "Tribes" in Cameron's Tanganyika. Tanzania Notes and Records 87:1-9.

Guha, Ranajit

1989 Dominance without Hegemony and its Historiography. In Subaltern Studies VI. Ranajit Guha, ed. Pp. 210-309. Delhi: Oxford University Press.

Hannerz, Uli

1987 The World in Creolisation. Africa 57:546-559.

Heussler, Robert

1963 Yesterday's Rulers. The Making of the British Colonial Service. London/Syracuse: Oxford Universily Press/Syracuse University Press.

Hirschkind, Charles

1991 Egypt at the Exhibition: Reflections on the Optics of Colonialism. A Review of Timothy Mitchell's Colonising Egypt. Critique of Antwropokgy 11:279-298.

Iliffe, John

1979 A Modern History of Tanganyika. Cambridge: Cambridge University Press.

Ingham, Kenneth

1965 Tanganyika: The Mandate and Cameron, 1919-1931. In History of East Africa, 2. Vincent Harlow and Emest Chilver, eds. Pp. 543 ..593. Nairobi: Oxford University Press.

Jourdan, Christine

1991 Pirdgins and Creoles: The Blurring of Categories. Annual Review of Anthropology 20:187-209.

Kirk-Greene, Anthony H. M. ed.

1965 The Principles of Native Administration in Nigeria. Selected Docurnents, 1900-1947. London: Oxiord University Press.

Kuklirk, Hemrik

1991 The Savage Within. The Social History of British Anthropology, 1885-1945. Cambridge: Cambridge University Press.

Kuper, Adam

1982 Lineage Theory: A Critical Retrospect. Annual Review of Anthropology 11:71-95.

Liebencow, 1. Gus

1971 Colenial Rule and Political Development in Tanzania. The Case of the Makonde. Nairobi: East Airican Publishing House.

ludden, David

1993 Orientalist Empiricism. In Orientalism and the Postcolonial Predicament. Carol Breckenridge and Peter van der Veer, eds. Pp. 250-278. Philadelphia: University of Pennsylvania Press.

Lugard, Frederick Dealtry

1970[1919] Political Memoranda, 1913-1918. Plymouth and London: Frank Cass.

Mackencie, John

1987 The Fmpire of Nature. Hunting, Conservation and British Imperialism. Manchester: Manchester University Press.

Malinowski, Bronislaw

1929 Practical Anthropology. Africa 2:22-38.

1930 The Rationalization of Anthropology and Administration. Africa 3:405-423

Mannheim, Karl

1960 Ideology and Utopia. An Introduction to the Sociology of Knowledge. Edward Shils, trans. London and Henley: Routledge and Kegan Paul.

Mitchell, Philip $\mathbf{E}$.

1930 The Anthropologist and the Practical Man. A Reply and a Question. Africa 3:217-223.

Mitchell, Timothy

1991 Colonising Egypt. 2nd ed. Berkeley: University of California Press.

Moliet John $P$.

1952 Native Courls in Tanganyika. Journal of African Administration 4:17-25.

Mruanda, Rev. Fr. Canute

1958 Plistoria ya Uluguru. Morogoro: Dincese of Morogoro. 
Pels, Peler

1994 The Construction of Ethnographic Occasions in Late Colonial Uluguru. History and Anthropology $8: 321-351$.

1995 The Politics of Aboriginality: Brian Houghton Hodgson and the Making of an Ethnology of India, Yearbosh or the International Institute ior Asian Studies 1994:147-168.

In press The Microphysics oi Crisis: Contac ob between Missionaries and Waluguru in Colonial Tanganyiha. 1930-1961. Chur, Switrerland: Harwood Arademis Publishers, 1997.

Pels, Peter, and Oscar Salemink

1994 Imeroduction: Five Theses on Finnography as Colonial Practice. History and Anthropology 8:1-34. Perham, Margery

1934 A Re-Statement of Indircet Rule. Afric a $7: 321-334$

Pelers, Emrys L.

1967 Some Structural Aspec ts of the Feud among the Camedt lerding Bedouin of Cyrenaica. Africa $37: 261-282$.

Prims, Gwymn

1980 The Hidden Hipunzotamus. Reappraisal in Alrican History: The Early Colonial Experience in Western Zambia. Combridge: Cambridge University Press.

Raiael, vicente $L$.

1994 White Lose: Censes and Nelodrama in the United States Colonization of the Philippines. History and Aalhropology $8: 26 ;-297$.

Ranger, Terence( ).

1980 Makmg Norhem Rhordesid Imperal. Airican Aliairs 79:349-373.

1983 The Imention of Iraditom in Colonial Arica. In The Invention of Tradirion. Eric I Iobsbawm and Terence O. Renger, eds. Pp. 211-262. Cambridge: Cambridge Universily Press.

Samarin. William!.

1484 The I inguinte World of Field Colonialism. Language in Society 13:435-453.

Srhumaker, Lymetle

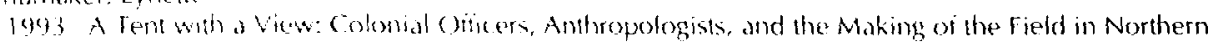
Rhoctesia, 193, 1906)

Sipulte Nordholt, llerik

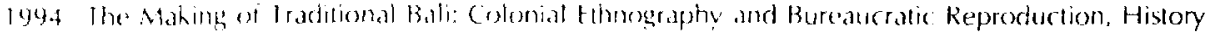
and sinthopelogy $8: 89-127$.

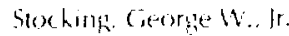

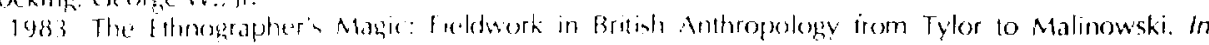

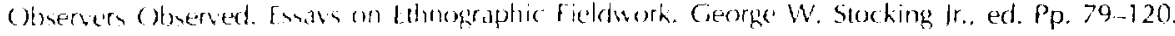
Mardison: Universily of Wiseomin Presis

Tage, John

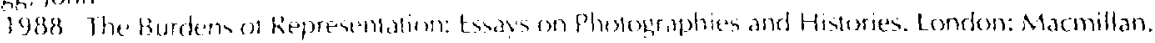

thesen van veleri. H. U. 1 .

19:3 Kobman Crused and Fridaly: Strength and Weakness of the Big Man Paradigm. Man (n.s.) $8.592 \cdot 612$.

Thomas, Nicholas

1991 Aganol fitmography. Cultural Anthropology 6:306-322

1992 The Inversion of Iradition. Americ an Ethnotogist 19:213-232.

1904 Colonialism's Culture, Anthopology, Iravel and Cosemment. Iondon: Polity Press.

Tyler. Sirphen

1984 The Vision (2uest in the West, or What the Mind's Eye Sees. fournal of Anthropological Research $40 ; 23-40$.

Wendelini, Mree Fius

n.d. Mibango ya Hintory yol Luguru. Z.amani Nipaka Siku tisi. Linpublished manuscripl.

Woolard, Kathryn, and Bambi Schiejelin

199.7 Language ldeology. Ammul Revew of Anthespology 23:55-832.

Young, Roland, and Henry Fosbrooke

1960 Land and Politios among the. Luguru of Tanganith. London: Routledge and Kregan Paul.

submitted April .29.1993

revised version submilted M.ly 30.1995

acrepled oclober 29,1995 